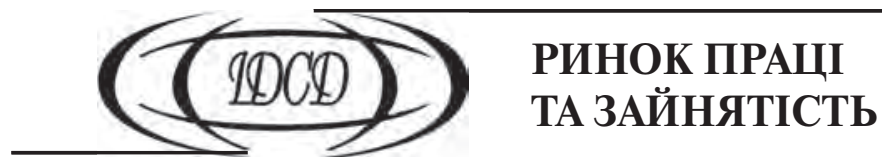

doi: $10.15407 /$ dse2016.03.158

УДК 331.522

JEL Classification: J13, J24

\title{
Л.А. ЛУТАЙ
}

д-р екон. наук, проф.

Інститут підготовки кадрів

Державної служби зайнятості України

03038, м. Київ, вул. Нововокзальна, 17

E-mail: lutay2012@yandex.ua

\section{С.Г. ПОМІНЧУК}

асп. каф. упр. персоналом та економіки праці

Інститут підготовки кадрів

Державної служби зайнятості України

заст. начальника від. надання соціальних послуг

Новобузький районний центр зайнятості

55601, Миколаївська область, м. Новий Буг, вул. Грушевського, 2

E-mail: svitlana.pominchuk.73@mail.ru

\section{НАПРЯМИ РОЗВИТКУ СИСТЕМИ ПРОФЕСІЙНОЇ ОРІЕНТАЦІЇ УЧНІВСЬКОЇ МОЛОДІ (на прикладі Миколаївської області)}

Основною метою дослідження є аналіз системи професійної орієнтації учнівської молоді та обгрунтування пріоритетів упровадження інноваційної програми професійної орієнтації учнівської молоді в державній служббі зайнятості на основі територіального підходу (на прикладі Миколаївської області). Проаналізовано стан сучасного ринку праці Миколаївської області та спроектовано прогнозні показники перспективного ринку праці з урахуванням стратегії економічного розвитку регіону. Представлені результати анкетування учнів загальноосвітніх навчальних закладів 10-11 класів Новобузького району Миколаївської області щодо їх професійного вибору свідчать, що лише п'ята частина учнів визначилися з подальшим професійним вибором, дві третини не знають потреб регіону в кадрах за професійною ознакою. Наведено перелік професій та видів діяльності, зазначених учнями для подальшого навчання. Доведено різнополюсовість діяльності ринку освітніх послуг та ринку праці. Запропонована інноваційна програма професійної орієнтації учнівської молоді в держсавній службі зайнятості на основі територіального (регіонального) підходу, яка дозволить об'єднати потреби ринку освітніх послуг та ринку праці в фахівцях, на яких є попит в конкретному регіоні. Це забезпечить зменшення кількості абітурієнтів за професіями, неактуальними на ринку праці регіону і призведе до функціональних змін на ринку праці, збільшення кількості малих підприємств за рахунок започаткування молоддю власної справи. Методи й алгоритм розроблено для вибору інноваційної програми професійної орієнтації школярів у державній службі зайнятості. Результати досліджень можуть бути застосовані фахівиями відділу надання соціальних послуг центрів зайнятості різних рівнів, а також науковиями, які займаються проблемами професійної орієнтації учнівської молоді.

Ключові слова: професійна орієнтація, учнівська молодь, регіон, регіональна економіка, ринок праці. 


\section{Л.А. Лутай}

Д-р экон. наук, проф.

Институт подготовки кадров

Государственной службы занятости Украины

03038, г. Киев, ул. Нововокзальная, 17

E-mail: lutay2012@yandex.ua

\section{С.Г. Поминчук}

асп. каф. упр.персоналом и экономики труда

Институт подготовки кадров

Государственной службы занятости Украины

зам.начальника отдела предоставления социальных услуг

Новобугский районный центр занятости

55601, Николаевская область, г. Новый Буг, ул. Грушевского, 2

E-mail: svitlana.pominchuk.73@mail.ru

\section{НАПРАВЛЕНИЯ РАЗВИТИЯ СИСТЕМЫ ПРОФЕССИОНАЛЬНОЙ ОРИЕНТАЦИИ УЧАЩЕЙСЯ МОЛОДЕЖИ (на примере Николаевской области)}

Основная цель исследования - анализ системы профессиональной ориентации учащейся молодежи и обоснование приоритетов внедрения инновационной программы профессиональной ориентации учащейся молодежи в государственной службе занятости на основе территориального подхода (на примере Николаевской области). Проанализировано состояние современного рынка труда Николаевской области и спроектированы прогнозные показатели перспективного рынка труда с учетом стратегии экономического развития региона. Представленные результаты анкетирования учащихся общеобразовательных учебных заведений 10-11 классов Новобугского района Николаевской области в отношении их профессионального выбора свидетельствуют, что лишь пятая часть учащихся определились с дальнейшим профессиональным выбором, две трети не знают потребностей региона в кадрах по профессиональному признаку. Приведен перечень профессий и видов деятельности, указанных учащимися для дальнейшего обучения. Доказана разнополюсность деятельности рынка образовательных услуг и рынка труда. Предложена инновационная программа профессиональной ориентации учащейся молодежи в государственной службе занятости на основе территориального (регионального) подхода, которая позволит объединить потребности рынка образовательных услуг и рынка труда в специалистах, на которых есть спрос в конкретном регионе. Это обеспечит уменьшение количества абитуриентов по неактуальным на рынке труда региона профессиям и приведет к функииональным изменениям на рынке труда, увеличению количества малых предприятий за счет создания молодежью собственного дела. Методы и алгоритм разработаны для выбора инновационной программы профессиональной ориентации школьников в государственной службе занятости. Результаты исследований могут быть использованы специалистами отдела предоставления социальных услуг центров занятости разных уровней, а также учеными, которые занимаются проблемами профессиональной ориентации учащейся молодежи.

Ключевые слова: профессиональная ориентация, учащаяся молодежь, регион, региональная экономика, рынок труда.

\section{L.A. Lutay}

Dr. Sc. (Economics), Prof.

Institute of Staff Training

of the State Employment Service of Ukraine

03038, Ukraine, Kyiv, Novovokzhalna Str., 17

E-mail: lutay2012@yandex.ua

\section{S.G. Pominchuk}

Postgraduate Department of Personnel Management and Labor Economics Institute of staff training of the State Employment Service of Ukraine Deputy head of the Department of social services 
The Novobugsky regional employment center

55601, Mykolaiv region, Noviy Bug, Hrushevsky str., 2

E-mail: svitlana.pominchuk.73@mail.ru

\section{DIRECTIONS OF DEVELOPMENT OF THE SYSTEM OF OCCUPATIONAL COUNSELLING FOR SCHOOL YOUTH (a Case of Mykolayiv Region)}

The main goal of the research is the analysis of the system of professional orientation of students and the rationale for prioritizing the implementation of innovative programs of professional orientation of students in state employment on the basis of territorial approach. The article analyzes the current state of the labor market of the Mykolaiv Oblast and promising prognostic indicators of the labor market, given the strategy of economic development of the region, are designed. The results of a survey of students of general educational institutions of 10-11 grades of the Novobugsky region of the Mykolaiv Oblast in relation to their professional choice indicate that only a fifth of students have determined their future professional choice, two-thirds do not know the needs of the region in personnel according to profession. A list of professions and types of activities specified by students for further study is given. The different poles of activities of the educational services market and the labor market are substantiated. An innovative program of professional orientation of students in state employment on the basis of territorial (regional) approach, which allows combining the needs of the education market and the labor market in specialists, for which there is demand in a particular region, is proposed. This will provide a reduction in the number of students in professions currently not relevant on the labor market of the region, and lead to an increase in the number of small businesses through the creation of youth owned business. Methods and the algorithm for selection of innovative programs of professional orientation of pupils in the public employment service are developed. The results of the research can be applied by the specialists of departments of social services employment centers of different levels, and scientists who are involved in the problems of professional orientation of students.

Keywords: professional orientation, students, region, regional economy, labor market.

Постановка проблеми. В Україні відсутня чітка й виважена система професійної орієнтації населення, не визначена сутність профорієнтаційної роботи в сучасних умовах, ії організаційна структура, пріоритетні напрями роботи та основні суб'єкти. Створення такої системи - одна з актуальних проблем сьогодення, бо їі відсутність суттєво ускладнює професійне самовизначення покоління, що зростає, працевлаштування безробітних, роботу служби зайнятості [1, с. 43].

Певного розповсюдження набула практика створення профорієнтаційного середовища як елемента взаємодії системи: загальноосвітній навчальний заклад - професійний навчальний заклад (найбільш розповсюджена система «СЗШ - ВНЗ», менш розповсюджена - «ПТНЗ - ВНЗ», існують поодинокі випадки створення систем «СЗШ - ПТНЗ») [2, с. 116]. Діяльність державної служби зайнятості з професійної орієнтації в цій ланці відсутня, хоча відповідно до ст. 6 Закону України «Про загальнообов'язкове державне соціальне страхування на випадок безробіття», молодь, яка закінчила або припинила навчання у загальноосвітніх, професійно-технічних і вищих навчальних закладах, має право на соціальні послуги, а згідно зі ст. 7 цього ж Закону професійна орієнтація є однією із соціальних послуг [3].

Надання якісних профорієнтаційних послуг громадянам, які підпадають під категорію соціально вразливих на ринку праці, до якої і належить молодь, залежить від фахового рівня спеціалістів центрів зайнятості, наявності у них відповідних дієвих знань і практичних навичок [4, с. 22].

Вчені зазначають, що маючи поверхневе уявлення про ринок праці та особливості працевлаштування в сучасних умовах, молодь, частіш за все, демонструє хибну поведінкову стратегію під час пошуку роботи, не має уявлення, яким чином можна подолати несприятливу ситуацію. Появі таких проблем можна було б запобігти, якби молодь своєчасно отримала необхідну допомогу з боку кваліфікованих профконсультантів. Е. Лібанова, досліджуючи молодіжний аспект ринку праці 2013 
року, зазначає, що для української молоді є характерним високий рівень освіти більше половини вже отримали або здобувають вищу освіту, а початковий рівень освіти мають лише 0,1 \% осіб віком 15-29 років. Понад 17,4 \% тих, хто навчається, поєднують здобуття освіти з економічною активністю на ринку праці. Більшість із них навчаються у вищих навчальних закладах. 55,5 \% молоді, яка закінчила навчання, має вищу освіту, ще 1,2 \% - післядипломну. 21,2 \% молоді закінчила заклади професійно-технічної освіти на базі повної загальної середньої освіти, 6,8 \% - базової загальної середньої [5, с. 17].

Сьогодні центри зайнятості вимушені перейматись проблемами профорієнтації учнівської молоді тому, що всі упущення у цій роботі значно ускладнюють процес працевлаштування, коли випускники навчальних закладів потрапляють на ринок праці. Розуміючи таке положення, центри державної служби зайнятості прикладають неабиякі зусилля, щоб допомогти навчальним закладам в організації та впровадженні профорієнтаційних заходів, але їхні можливості щодо цього суттєво обмежені [1, с. 47].

Ефективний взаємозв’язок ринку освітніх послуг з ринком праці за більш ніж двадцять років побудови ринкових відносин в Україні так і не сформований. Згідно з Законом України «Про зайнятість населення», ринок праці - система правових, соціально-трудових, економічних та організаційних відносин, що виникають між особами, які шукають роботу, працівниками, професійними спілками, роботодавцями та їх організаціями, органами державної влади у сфері задоволення потреби працівників у зайнятості, а роботодавців - у найманні працівників відповідно до законодавства [6].

Одне із пояснень, які надають науковці досліджуючи дисбаланс між професійною освітою і працею за конкретною спеціальністю, є таким: система освіти у своїй діяльності орієнтується переважно на попит домогосподарств як «постачальників» абітурієнтів і споживачів освітніх послуг. У той час як попит на робочу силу фахівців формують на ринку праці роботодавці. При цьому система освіти через нестачу достовірної, а головне - повної інформації про реальні потреби економіки продовжує діяти за інерцією, не «вловлює» сигналів ринку праці [7, с. 6].

Науковці зазначають, що саме професійна орієнтація учнівської молоді відіграє важливу для ринку праці роль: сприяє превентивному формуванню пропозиції робочої сили, впливає на формування ринку освітніх послуг. Саме профорієнтаційна робота є одним із найефективніших методів допомоги учнівській молоді у виборі професії [8, с. 38].

Аналіз останніх досліджень і публікацій. У ході проведеного дослідження виявлено, що переважна більшість наукових напрацювань щодо професійної орієнтації учнівської молоді здійснена представниками педагогічно-психологічних наук. Ці наукові праці присвячені психологічній стороні вибору професії: дослідження здібностей, задатків учня, його готовності до вибору професійної діяльності, спираються на психологічне підгрунтя, початкові складові формули вибору професії - «хочу» i «Мжу».

Д.О. Закатнов (D.O. Zakatnov) досліджував технології підготовки учнівської молоді до професійного самовизначення. О.В. Лавріканець (O.V. Lavrikanets) вивчала форми профорієнтаційної роботи з учнівською молоддю. Н.Л. Отрощенко (N.L. Otroschenko) професійну орієнтацію розглядала як соціально-педагогічну проблему. О.М. Пильтяй (О.M. Руltyay) вивчала вплив ринку праці на професійну орієнтацію школярів. Н.А. Побірченко (N.A. Pobirchenko) досліджувала професійну орієнтацію як наукову дисципліну. Е.M. Ахромкін (Е.M. Ahromkin) та O.В. Пере- 
пелюкова (O.V. Perepelyukova) вивчали вплив ринку освітніх послуг на формування трудового потенціалу регіону.

Вагомий внесок із впровадження технологій професійного самовизначення здійснили зарубіжні вчені Д. Голланд (J. Holland) та С. Фукуяма (S. Fukuyama).

Професійній орієнтації в службі зайнятості присвячені наукові праці Л.Г. Авдєєва, Ю.М. Маршавіна, М.А. Міропольської, Н.В. Ортікової та інших.

Л.Г. Авдєєв (L.G. Avdeev) досліджував стан та перспективи розвитку професійної орієнтації в Україні, Н.В. Ортікова (N.V. Ortikova) та М.А. Міропольська (M.A. Miropolska) вивчали професійну орієнтацію безробітних громадян та молоді. Ю.М. Маршавін (Yu.M. Marshavin) досліджував ефективність професійної орієнтації в службі зайнятості, іiї економічну сутність для попередження молодіжного безробіття та прогнозування розвитку ринку праці.

Науковці зазначають, що для успішної інтеграції молоді в ринок праці потрібно продовжити реформування традиційної системи освіти, створювати професійно різні в структурному плані системи підготовки, здійснювати заходи зі збалансування потреб місцевої економіки і ринку праці з можливостями системи освіти і професійної підготовки [9, с. 219].

Слабкими місцями сучасної професійної орієнтації учнівської молоді є:

- відсутність професійних консультантів (профконсультантів) у штатній чисельності загальноосвітніх навчальних закладів;

- обмеженість інформації в структурі профорієнтаційних заходів (переважно психологічно-педагогічні характеристики особистості);

- перевантаженість профорієнтаційних заходів ігровими методами;

- відсутність системного підходу до проведення профорієнтаційних заходів як у загальноосвітніх навчальних закладах, так і спеціалістами служби зайнятості;

- відсутність єдиної технології проведення профорієнтаційних заходів у державній службі зайнятості.

Метою статті є формування теоретико-методологічних засад здійснення професійної орієнтації учнівської молоді в державній службі зайнятості на основі територіального підходу.

Виклад основного матеріалу. Позаурочні профорієнтаційні заходи - це основа профорієнтаційної роботи в школі. Д.О. Закатнов констатує, що головна мета системи позаурочних профорієнтаційних заходів полягає у формуванні в учнів готовності до професійного самовизначення. Зазначена мета реалізується в процесі розв'язання комплексу таких виховних навчальних завдань:

- ставлення до себе як до суб’єкта професійної діяльності, усвідомлення своєї індивідуальної неповторності, відповідальності за прийняття рішень щодо власного професійного майбутнього;

- формування систематизованих знань щодо світу професійної праці;

- вивчення сучасних вимог до фахівців на ринку праці, тактики та стратегії власного розвитку як професіонала;

- розвиток здатності до самопізнання, самооцінки, самоаналізу та актуалізація потреби в самовдосконаленні [2, с. 117].

Науковці констатують, що в організаційному плані сьогодні в школах ключовою фігурою, яка відповідає за здійснення профорієнтаційної роботи, є практичні психологи. Єдиними освітніми закладами, в яких досі існує посада методиста 3 профорієнтації, є міжшкільні навчально-виробничі комбінати, але їх кількість за 
останні два десятиріччя суттєво скоротилася, школа не виконує поставлених завдань із професійної орієнтації, оскільки немає формальних зобов’язань перед державою в галузі професійної орієнтації учнів [2, с. 115].

У наукових працях вчених присутні елементи критичного підходу до орієнтації учнівської молоді на професії, які потрібні ринку праці, але такий підхід не враховує індивідуальних психологічних задатків і здібностей, успадкувавши від СРСР систему освіти, яка була орієнтована на задоволення планової економіки у відтворенні та розвитку професійного потенціалу. Досліджуючи генезис професійної орієнтації, а саме доробок таких дослідників як Т. Мальковська, І. Аванесян, Т. Бугорина, які виділяють з поміж психологічних задатків та здібностей ще й такі компоненти профорієнтації як: інформація про професії, необхідні національному господарству, шляхи оволодіння ними, потреби місцевого ринку праці, у якому мешкає учнівська молодь й орієнтацію на ці професії, варто відмітити, що в такому розумінні вчені вживають термін «трудова гіперорієнтація», на зміну якій прийшла профільна школа, що набула рис класичної академічної освіти, яка готує школярів до набуття вищої, переважно гуманітарної освіти [2, с. 87].

В умовах сьогодення відбулись «перекоси» від «трудової гіперорієнтації» до «психолого-педагогічного» ракурсу і орієнтації на внутрішнє бажання. Дослідження свідчать, що практично кожен третій випускник середнього загальноосвітнього навчального закладу обирає собі майбутню професію стихійно, без усебічного аналізу реальних і потенційних ресурсів, оцінювання можливостей їх мобілізації для досягнення визначеної мети, корекції своїх фахових уподобань із довготривалими тенденціями кон'юнктури професій тощо. Існує дуже сильна залежність вибору від випадкових факторів, наприклад, порад друзів або знайомих, гонитва за модною професією [4, с. 16].

Як свідчить статистика, молодь становить третину загальної чисельності клієнтів державної служби зайнятості. Майже щорічно до цього загону приєднуються понад 100 тис. випускників навчальних закладів різних типів. 3 них 37 \% - випускники вищих навчальних закладів, 33 \% - випускники навчально-виховних закладів, решта $30 \%$ - випускники загальноосвітніх шкіл. Опинившись на ринку праці такі особи потрапляють у скрутне становище - без професії, життєвого та професійного досвіду вони не здатні на рівних конкурувати з представниками інших вікових категорій $[1$, c. 46].

Центри зайнятості охоче відгукуються на запрошення шкіл і беруть участь у профорієнтаційних заходах. Вони запрошують учнів до себе, знайомлять із напрямами своєї діяльності, пропонують послуги; залучають учнів до таких заходів профорієнтаційного характеру як ярмарки вакансій, дні професій, конкурси за професіями тощо [1, с. 47].

Наявність структурної диспропорції між попитом на робочу силу та її пропозицією є фактором, що обмежує як можливості працевлаштування безробітних, так і задоволення потреб роботодавців. Для попередження цього у економічно розвинутих країнах розробленні методи прогнозування перспективного ринку праці, міжгалузева макромодель прогнозування зайнятості SONIA, яка дає можливість будувати прогнози на 10 років, здійснювати розрахунки міжгалузевого балансу трудових ресурсів на рівні видів економічної діяльності [10].

Спеціалісти центрів зайнятості, володіючи актуальною інформацією щодо конкурентоспроможних спеціальностей і потреб ринку праці, а також маючи ресурси та 
відповідний інструментарій з орієнтації молоді на необхідні професії, значною мірою можуть допомогти педагогічним колективам шкіл у навчально-виховній роботі щодо професійного самовизначення учнів [4, с. 16].

3 урахуванням вищенаведеного необхідно розробити інноваційну програму професійної орієнтації учнівської молоді на основі територіального підходу. Для цього необхідно провести дослідження стану та перспектив розвитку конкретного регіону.

Регіон (лат. regionis - область, район) - теорія, яка відрізняється від інших низкою ознак і характеризується певною цілісністю та взаємопов'язаністю її складових елементів [11].

Миколаївський регіон належить до приморських територій. Миколаївська область - це високорозвинений регіон держави, який визначається потужною багатогалузевою промисловістю, що має дуже важливе значення в структурі народногосподарського комплексу України. Природні та кліматичні умови області сприятливі для інтенсивного високоефективного розвитку сільського господарства [12, с. 59].

У Миколаївській області функціонує потужна транспортна система, до складу якої входить залізничний, морський, річковий, автомобільний, авіаційний та трубопровідний транспорт. Миколаївська область має значний рекреаційний потенціал. Перелік населених пунктів, віднесених до курортних: села Василівка, Покровка, Чорноморка Очаківського району, місто Очаків, села Вікторівка, Коблево, Морське, Лугове, Рибаківка Березанського району. Перелік водних об’єктів, родовищ мінеральних вод - Очаківське, Коблевське, Казанківське, родовищ лікувальних грязей - Бейкушське, Тилігульське. На території курортних зон Миколаївської області працюють бази відпочинку: с. Коблево - 81, с. Рибаківка - 61, с. Лугове -13 , с. Морське - п'ять, с. Чорноморка - 37, с. Покровка - одна, м. Очаків - сім. На території області функціонує сім лікувальних санаторіїв та пансіонатів, 111 санаторіїв та закладів відпочинку, дев'ять санаторіїв-профілакторіїв, 14 будинків відпочинку й пансіонатів та 81 база відпочинку [12, с. 60].

Задля реалізації людського, наукового та залишків матеріального ресурсу в галузі суднобудування дослідники розвитку регіону пропонують перехід від великомасштабного та військового кораблебудування на комерційне та приватне [12, с. 62].

Стан сучасного ринку праці України та Миколаївської області проаналізовано за допомогою показників попиту на робочу силу. У 2015 році найбільший відсоток працевлаштованих безробітних в Україні спостерігався в таких галузях як сільське, лісове та рибне господарство (26,9\%), переробна промисловість (16,6\%), оптова та роздрібна торгівля, ремонт автотранспортних засобів (16,1\%), державне управління й оборона, обов'язкове соціальне страхування (6\%), освіта (6 \%), охорона здоров'я та надання соціальної допомоги (4 \%), транспорт, складське господарство, поштова та кур'єрська діяльність $(4,4 \%)[13,14]$.

У Миколаївській області найбільша кількість працевлаштованих у 2015 році в сільському, лісовому та рибному господарстві (42,6 \%), переробній промисловості (10\%), оптовій і роздрібній торгівлі, в галузі ремонту автотранспортних засобів $(9,8 \%)$, державному управлінні й обороні $(6,8 \%)$, освіті $(7,7 \%)[13,14]$.

Перспективність ринку праці Миколаївської області прогнозована шляхом вивчення ситуації на ринку освітніх послуг, а само: чисельності випускників навчальних закладів регіону, які є ресурсами для забезпечення перспективного ринку праці, та шляхом опитування учнів загальноосвітніх навчальних закладів щодо вибору професійної діяльності. 
Таблиця 1. Кількість вищих навчальних закладів та підготовка фахівців в Україні та Миколаївській області

\begin{tabular}{|c|c|c|c|c|c|c|c|c|c|c|c|c|}
\hline \multirow[b]{3}{*}{ Показник } & \multicolumn{12}{|c|}{ I - IV рівнів акредитації } \\
\hline & \multicolumn{2}{|c|}{$2010-2011$} & \multicolumn{2}{|c|}{ 2011-2012 } & \multicolumn{2}{|c|}{ 2012-2013 } & \multicolumn{2}{|c|}{ 2013-2014 } & \multicolumn{2}{|c|}{ 2014-2015 } & \multicolumn{2}{|c|}{$2015-2016$} \\
\hline & 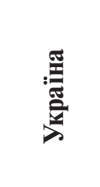 & 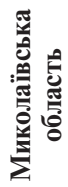 & 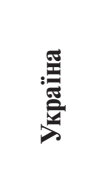 & 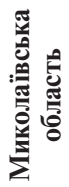 & 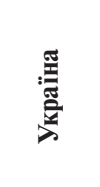 & 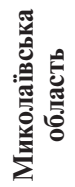 & 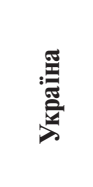 & 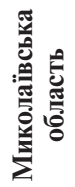 & 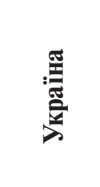 & 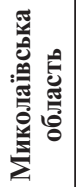 & 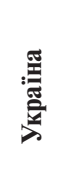 & 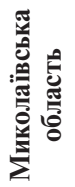 \\
\hline $\begin{array}{l}\text { Кількість } \\
\text { закладів, } \\
\text { усього, } \\
\text { одиниць }\end{array}$ & 813 & 16 & 805 & 16 & 785 & 15 & 767 & 17 & 664 & 17 & 659 & 16 \\
\hline $\begin{array}{l}\text { Випу- } \\
\text { щено, } \\
\text { усього, } \\
\text { осіб }^{1}\end{array}$ & 636291 & 13,8 & 609033 & 15 & 595251 & 15,2 & 560381 & 12,1 & 484482 & 11,9 & & \\
\hline
\end{tabular}

${ }^{1}$ Випущено фахівців (без тих, що закінчили відповідний цикл навчання, зокрема бакалаврат, та продовжують навчання з метою здобуття більш високого освітньо-кваліфікаційного рівня).

Джерело: Державна служба статистики України; головне управління статистики в Миколаївській області.

В Україні випуск вищими навчальними закладами фахівців із вищою освітою перевищує на $34 \%$ випуск робочих кадрів. У Миколаївській області випуск вищими учбовими закладами слухачів з вищою освітою перевищує випуск робочих кадрів на $52 \%$ (табл. 1, 2.) [13, 14].

Кількість випускників вищих навчальних закладів, які отримали направлення на роботу у 2015 році в Україні становить 21,9\% від загальної кількості, у Миколаївській області цей відсоток становить 29,1 \% (табл. 3) [13, 14].

Як свідчать підсумки роботи ПТНЗ в Україні у 2014/2015 навчальному році, вісім 3 кожних десяти випускників $(79,1 \%)$ працевлаштовані за професією. Найбільша кількість працевлаштованих (78,5 \%) отримала роботу за договорами на підприємствах, в організаціях, за квотою для молоді. Найбільше випускників професійно-навчальних закладів працевлаштовані у промисловості (31 \%), торгівлі і громадському харчуванні (19,6\%), транспортних підприємствах - 16 \% [13].

У процесі дослідження виконано анкетування учнів загальноосвітніх навчальних закладів 10-11 класів (291 учень) Новобузького району Миколаївської області щодо їх професійного вибору.

Учням було запропоновано наступну схему аналізу обраної ними професії (перелік основних характеристик професії): предмет праці, мета, засоби праці, умови праці, характер спілкування у праці, відповідальність у праці, особливості роботи, типові труднощі, з якими стикається людина у ході праці, мінімальний рівень освіти, необхідний для оволодіння професією, місце роботи по закінченню навчального закладу.

Опитування показало, що лише $21 \%$ учнів визначилися з подальшим професійним вибором, з них 14 \% назвали професію і галузі її застосування, наводили приклади навчальних закладів, у яких можна отримати обрану професію. Респонденти даної категорії володіють знаннями про предмет праці обраної професії (буде працювати з 
Таблиця 2. Кількість професійно-технічних навчальних закладів та підготовка робітників в Україні та Миколаївській області

\begin{tabular}{|c|c|c|c|c|}
\hline \multirow{2}{*}{ Рік } & \multicolumn{3}{|c|}{ Кількість закладів } & \multicolumn{2}{|}{$\begin{array}{c}\text { Підготовлено (випущено) кваліфікованих } \\
\text { робітнив, тис. }\end{array}$} \\
\cline { 2 - 5 } & Україна & Миколаївська область & Україна & Миколаївська область \\
\hline 2011 & 976 & 32 & 240,1 & 7,7 \\
\hline 2012 & 972 & 32 & 202,1 & 6,8 \\
\hline 2013 & 968 & 32 & 227,3 & 7,8 \\
\hline $2014^{1}$ & 814 & 32 & 182,0 & 7,3 \\
\hline $2015^{1}$ & 798 & 32 & 165,0 & 6,2 \\
\hline
\end{tabular}

${ }^{1}$ Без урахування тимчасово окупованої території Автономної Республіки Крим, м. Севастополь та частини зони проведення антитерористичної операції.

Джерело: Державна служба статистики України; головне управління статистики в Миколаївській області.

Таблиця 3. Кількість випускників ВНЗ, які отримали направлення на роботу у 2015 році, в Україні та Миколаївській області

\begin{tabular}{|c|c|c|c|c|c|}
\hline \multirow{2}{*}{ Регіон } & \multicolumn{2}{|c|}{$\begin{array}{c}\text { Кількість випускників, які } \\
\text { отримали направлення на } \\
\text { роботу }\end{array}$} & \multicolumn{2}{|c|}{$\begin{array}{c}3 \text { них навчалися за рахунок } \\
\text { коштів бюджету, осіб }\end{array}$} & \multirow{2}{*}{$\begin{array}{c}\text { Кількість випуск- } \\
\text { ників, які одно- } \\
\text { часно з освітнь-- } \\
\text { кваліфікаційним } \\
\text { рівнем отримали } \\
\text { робітничу про- } \\
\text { фесію, осіб }\end{array}$} \\
\hline & Усього, осіб & $\begin{array}{c}\text { у \% до загаль- } \\
\text { ної кількості } \\
\text { випускників }\end{array}$ & державного & місцевих & \\
\hline Україна & 98037 & 21,9 & 74678 & 13643 & 30445 \\
\hline Миколаївська & 2566 & 29,1 & 1560 & 600 & 895 \\
\hline
\end{tabular}

Джерело: Державна служба статистики України; головне управління статистики в Миколаївській області.

людьми, технікою, тваринами, рослинами, знаковими системами та ін.), цікавились, де будуть працювати за обраними професіями, зазначили заплановане місце подальшої роботи після закінчення навчального закладу.

$4 \%$ опитаних учнів знають лише назву професії, не володіють знаннями про види навчальних закладів, не визначились із навчальним закладом для отримання професії, сумніваються у предметі праці обраної професії, не володіють інформацією щодо радіусу застосування професійних знань.

$2 \%$ респондентів визначились із видом діяльності, визначають предмет праці (буду працювати з людьми, тваринами, рослинами, технікою та ін.), але назву професії не називають. 79 \% опитаних учнів не визначились з обраною професією, 84 \% не цікавились потребами свого регіону в кадрах.

Перелік професій та видів діяльності, зазначених учнями для подальшого навчання: органи правопорядку (міліціонер, поліцейський, слідчий, інкасатор) $24 \%$, сільське господарство (агроном, бджоляр) - $10 \%$, IT-технології - $10 \%$, освіта і наука (вихователь дошкільного навчального закладу, вчитель іноземної мови) - 10 \%, енергетика (інженер - енергетик) - 5\%, сфера обслуговування (перукар, дизайнер) $10 \%$, медицина та фармація (стоматолог, фармацевт, лікар, акушер, сестра медична) $19 \%$, морський транспорт (моряк) - $5 \%$, банківська справа $-5 \%$. 
Порівнявши галузі перспективного розвитку регіону [12] та вибір учнів, можна відзначити відсутність у виборі таких галузей як залізничний, річковий, автомобільний, авіаційний та трубопровідний транспорт, галузі суднобудування (військове кораблебудування, комерційне та приватне), низький відсоток обраних професій у морському транспорті; не називають учні й рекреаційну зону як перспективну для подальшого працевлаштування, відсутня у виборі готельно-ресторанна галузь, а значить, можливість започаткування власної справи. В разі економічного зростання зазначених галузей, які визначені перспективними для розвитку інфраструктури регіону, паралельно буде відбуватись розвиток соціальної інфраструктури, що забезпечить створення нових робочих місць.

Виходячи із досліджень вибору професії учнівською молоддю, кількості випускників ВНЗ та потреби ринкової економіки, лише за 2015 рік спостерігається абсолютна різнополюсовість діяльності ринку освітніх послуг та ринку праці: старшокласники не знають про перспективні галузі в регіоні, перспективи працевлаштування за обраною професією. Вибір учнів загальноосвітніх навчальних закладів знаходиться поза сферою потреб ринку праці.

Науковці зазначають, що таку небезпечну тенденцію може подолати перехід на регіонально-галузевий принцип планування потреби в підготовці робітників і фахівців у закладах початкової, середньої та вищої професійної освіти. Це один із дієвих заходів взаємодії органів освіти і служби зайнятості [7, с. 7]. Для практичного втілення вищеозначеного принципу необхідна інноваційна програма, суть якої полягає у впровадженні уніфікованих, системних профорієнтаційних уроків «Техніка вибору професії» одночасно у всіх загальноосвітніх навчальних закладах держави у 1-11 класах. Алгоритм дії профконсультанта державної служби зайнятості під час здійснення інноваційної програми професійної орієнтації такий: вивчення потреб регіонального ринку праці в кадровому забезпеченні, застосування отриманої інформації в чотирьохетапній методиці «Техніка вибору професії з урахуванням вікових особливостей дітей у кожній ланці загальноосвітньої школи:

І етап - «Світ професій»;

II етап - «Моя професія у світі професій»;

III етап - «Я і моя професія»;

IV етап - «Майбутнє обираю сьогодні».

Авторська концепція інноваційної професійної орієнтації є регіональноцентрованою поліпрофорієнтацією, яка надасть системні знання щодо потреб і перспектив кадрового розвитку регіонів. Наявна програма професійної орієнтації школярів у державній службі зайнятості зараз спирається на психолого-педагогічні аспекти, а макроекономічні засади, зокрема територіальний підхід, залишаються поза сферою дослідження. Зміст сучасної шкільної освіти недостатньо адаптований до майбутніх потреб учнів за межами школи.

Для впровадження авторської концепції необхідно:

- розроблення та впровадження методики прогнозування перспективного ринку праці на державному рівні, що дасть можливість ознайомлювати учнівську молодь із потребами регіонального ринку праці; включення до науковометодичного забезпечення професійної орієнтації професійної пропаганди пріоритетних видів діяльності в окремих регіонах та країні загалом;

- розроблення науково-методичного забезпечення здійснення профорієнтаційних заходів спеціалістами служби зайнятості в усіх ланках загальноосвітньої школи; 
- оновлення структури, змісту, форм і методів професійної орієнтації в усіх ланках загальноосвітньої школи;

- формування кадрового складу спеціалістів з професійної орієнтації в державній службі зайнятості.

Це забезпечить:

- функціональні зміни на ринку освітніх послуг: зменшення кількості абітурієнтів за професіями неактуальними, на ринку праці регіону (зміниться пропозиція);

- функціональні зміни на ринку праці (зміниться попит); збільшиться кількість малих підприємств за рахунок започаткування молоддю власної справи у тих видах діяльності, на якіє попит.

Ризики впровадження інноваційної програми професійної орієнтації:

- складна передбачуваність напрямів розвитку потреб ринку праці;

- нелегальна, прихована зайнятість у перспективних галузях економіки;

- стереотипність мислення дорослого населення (батьків) щодо вибору професії учнівською молоддю, низька поінформованість домогосподарств про розвиток регіону;

- орієнтація навчальних закладів на потребу домогосподарств;

- матеріальні затрати для впровадження оновленої програми професійної орієнтації (збільшення чисельності профорієнтаторів у службі зайнятості, оновлення методичного забезпечення здійснення професійної орієнтації учнівської молоді в загальноосвітніх навчальних закладах).

Висновки. У результаті проведеного дослідження:

- проаналізовано сучасний стан системи професійної орієнтації учнівської молоді;

- встановлено, що професійна орієнтація є вторинним аспектом діяльності школи;

• наведено перелік професій і видів діяльності, зазначених учнями для подальшого навчання;

- доведено різнополюсовість діяльності ринку освітніх послуг і ринку праці;

- доведено, що традиційна система професійної орієнтації учнівської молоді в державній службі зайнятості немає єдиної системної базової технології;

- доведено, що організація ефективної професійної орієнтації неможлива без урахування особливостей потреб ринку праці регіону у змісті цієї орієнтаціï;

• рекомендовано оновлений алгоритм дій для організації професійної орієнтації учнівської молоді на основі регіонально-галузевого принципу;

- встановлено необхідність організації корекційно-кадрових заходів щодо підготовки фахівців до впровадження інноваційної програми професійної орієнтації.

За результатами дослідження рекомендовано здійснити структуризацію програми професійної орієнтації в службі зайнятості з урахуванням територіальних і галузевих аспектів, умов розвитку окремих регіонів, що вплине на формування економічних знань учнівської молоді щодо поточного і перспективного попиту регіональних суб'єктів на перспективне кадрове забезпечення.

Грунтовне інформування учнів про регіональні особливості та потреби регіональної економіки створить для майбутнього випускника навчального закладу конкурентні переваги на ринку праці фахівців із вищою освітою. Інноваційна програма 
професійної орієнтації надасть учнівській молоді економічні знання про регіони та сприятиме свідомому вибору професійної діяльності.

Виконане дослідження не вичерпує всіх аспектів обраної проблеми професійної орієнтації та не забезпечує запобігання молодіжному безробіттю через дисбаланс попиту та пропозиції на ринку праці. Перспективи подальших розвідок передбачають проведення експериментальної частини дослідження на підставі розроблених теоретико-методологічних засад інноваційної програми професійної орієнтації учнівської молоді в державній службі зайнятості.

\section{ЛІТЕРАТУРА}

1. Авдєєв Л.Г.Стан та перспективи розвитку професійної орієнтації в Україні: наук.-метод. посіб. для працівників служби зайнятості / Л.Г. Авдєєв - К. : ІПК ДСЗУ, 2012. - 64 с.

2. Д.О. Закатнов. Технології підготовки учнівської молоді до професійного самовизначення: монографія / Д.Л. Закатнов - К. : Педагогічна думка, 2012. - 160 с.

3. Закон України «Про загальнообов'язкове державне соціальне страхування на випадок безробіття» [Електронний ресурс]. - Режим доступу : http://zakon5.rada.gov.ua/laws/show/1533-14

4. Авдєєв Л.Г., Ортікова Н.В. Професійна орієнтація безробітних громадян та молоді : навч.- метод. розробка / Л.Г. Авдєєв, Н.В. Ортікова - К. : ІПК ДСЗУ, 2013. - 55 с.

5. Перехід на ринок праці молоді України / Елла Лібанова, Олександр Цимбал, Лариса Лісогор, Ірина Марченко, Олег Ярош // Міжнародне бюро праці, Програма молодіжної зайнятості, Департамент політики зайнятості. - Женева : МОП, 2014 (Work4Youth publication series; No. 11 (web pdf )) [Електронний ресурс] - Режим доступу : http://www.ilo.org/employment/areas/youth-employment/work-for-youth/publications/national\%20reports/WCMS_30264"/WCMS_30264

6. Закон України «Про зайнятість населення» [Електронний ресурс]. - Режим доступу: http:// zakon3.rada.gov.ua/laws/show/5067-17

7. Ахромкін Е.M., Перепелюкова О.В. Вплив ринку освітніх послуг на формування трудового потенціалу регіону // Економіка та право. - 2012. - № 1. - С. 5-8 [Електронний ресурс]. - Режим доступу : http://www.nbuv.gov.ua/old_jrn/Soc_Gum/Epravo/2012_1/1.pdf

8. Лавріканець О.В. Форми профорієнтаційної роботи з учнівською молоддю / О.В. Лавріканець // Ринок праці та зайнятість населення. - 2010. - № 4. - С. 38-40.

9. Пильтяй О.М. Вплив ринку праці на професійну орієнтацію школярів в Україні [Електронний pecypc]. - Режим доступу : http://enpuir.npu.edu.ua/bitstream/123456789/8176/1/Piltyay.pdf

10. Маршавін Ю.М. Прогнозування розвитку ринку праці як чинник продуктивної зайнятості населення // Матеріали Міжнародної науково-практичної конференції «Ринок праці України: Свропейський вимір» (25 червня 2015 р., м. Київ) [Електронний ресурс]. - Режим доступу : http://ipk-dszu.kiev.ua/laboratory/prezent/marshavin\%20(u).pdf

11. Словник термінів [Електронний ресурс] - Режим доступу : http://pidruchniki.com/10730307/ rps/slovnik terminiv

12. Стан та перспективи розвитку інфраструктури регіонів України [Електронний ресурс]. - Режим доступу : http://www.fes.kiev.ua

13. Державна служба статистики України [Електронний ресурс] - Режим доступу : http://www. ukrstat.gov.ua/druk/publicat/kat_u/2015/dop/04/dop_pr_2016.z.p

14. Головне управління статистики в Миколаївській області [Електронний ресурс]. - Режим доступу : http://www.mk.ukrstat.gov.ua

\section{REFERENCES}

1. Avdieiev, L.H. (2012). Stan ta perspektyvy rozvytku profesijnoi oriientatsii v Ukraini [Stan and prospects of career guidance in Ukraine]. Kyiv: IPK DSZU [in Ukrainian].

2. Zakatnov, D.O. (2012). Tekhnolohii pidhotovky uchnivs'koi molodi do profesijnoho samovyznachennia [Technology training pupils to professional self]. Kyiv: Pedahohichna dumka [in Ukrainian].

3. Zakon Ukrainy «Pro zahalnooboviazkove derzhavne sotsialne strakhuvannia na vypadok bezrobittia» [The low of Ukraine «On compulsory state social Unemployment Insurance»]. (n.d.). zakon.rada.gov. ua. Retrieved from http://zakon5.rada.gov.ua/laws/show/1533-14 [in Ukrainian]. 
4. Avdieiev, L.H. \& Ortikova, N.V. (2013). Profesiina oriientatsiia bezrobitnykh hromadian ta molodi [Professional targeting the unemployed and young people]. Kyiv: IPK DSZU [in Ukrainian].

5. Libanova, E., Tsymbal, O. \& Lisohor, L. (2014). Perekhid na rynok pratsi molodi Ukrainy [The transition to the labor market young Ukraine]. Zheneva: MOP Retrieved from http://www.ilo.org/employment/areas/ youth-employment/work-for youth/publications/national\%20reports/WCMS_30264"/WCMS_30264 [in Ukrainian].

6. Zakon Ukrainy «Pro zainiatist naselennia» [The low of Ukraine «On Employment»]. (n.d.). zakon.rada. gov.ua. Retrieved from http://zakon3.rada.gov.ua/laws/show/5067-17 [in Ukrainian].

7. Akhromkin, E.M. \& Perepeliukova, O.V. (2012). Vplyv rynku osvitnikh posluh na formuvannia trudovoho potentsialu rehionu [The impact of the educational market in the formation of labor potential of the region]. Ekonomika ta pravo - Economics and Law, 1, 5-8. Retrieved from http://www.nbuv.gov. ua/old_jrn/Soc_Gum/Epravo/2012_1/1.pdf [in Ukrainian].

8. Lavrikanets', O.V. (2010). Formy proforiientatsiinoi roboty z uchnivskoiu moloddiu [Forms vocational guidance of pupils]. Rynok pratsi ta zajniatist' naselennia - The labor market and employment, 4, 38-40 [in Ukrainian].

9. Pyltiai, O.M. Vplyv rynku pratsi na profesiinu oriientatsiiu shkoliariv v Ukraini [The impact of the labor market for professional orientation of students in Ukraine]. (n.d.). enpuir.npu.edu.ua Retrieved from http://enpuir.npu.edu.ua/bitstream/123456789/8176/1/Piltyay.pdf [in Ukrainian].

10. Marshavin, Yu.M. (2015). Prohnozuvannia rozvytku rynku pratsi yak chynnyk produktyvnoi zainiatosti naselennia [Prediction of the labor market as a factor in productive ]. Mizhnarodna naukovo-praktychna konferentsiia «Rynok pratsi Ukrainy: Yevropeiskyi vymir» (25 chervnia 2015 roku) - International scientificpractical conference «The labor market in Ukraine: European Dimension». Retrieved from http://ipk-dszu. kiev.ua/laboratory/prezent/marshavin\%20(u).pdf [in Ukrainian].

11. Slovnyk terminiv [Slovnyk terms]. (n.d.). pidruchniki.com. Retrieved from http://pidruchniki.com/ 10730307/rps/slovnik terminiv [in Ukrainian].

12. Stan ta perspektyvy rozvytku infrastruktury rehioniv Ukrainy [Stan infrastructure and prospects of Ukraine's regions]. (n.d.). fes.kiev.ua. Retrieved from http://www.fes.kiev.ua [in Ukrainian].

13. Sait «Derzhavna sluzhba statystyky Ukrainy» [Site «Statistics Service of Ukraine»]. ukrstat.gov.ua. Retrieved from http://www.ukrstat.gov.ua/druk/publicat/kat_u/2015/dop/04/dop_pr_2016.z.p [in Ukrainian].

14. Sait «Holovne upravlinnia statystyky v Mykolaivs'kij oblasti» [Site «Department of Statistics in the Mykolaiv region»]. mk.ukrstat.gov.ua. Retrieved from http://www.mk.ukrstat.gov.ua [in Ukrainian].

Стаття надійшла до редакції журналу 13.06.2016. 